\title{
BEMUTATKOZIK A NÉMET RÉGÉSZETI INTÉZET FRANKFURTI PROSPEKCIÓS ÉS ÁSATÁS-MÓDSZERTANI KÖZPONTJA
}

\author{
Knut Rassmann - Isabel Hohle - Roman Scholz - Hajo Höhler-Brockmann - Johannes Kalmbach - \\ Jessica Schmauderer - Maria Kohle - Melani Podgorelec - Bánffy Eszter \\ Magyar Régészet 9. évf. (2020), 1. szám, pp. 50-54. doi: https://doi.org/10.36245/mr.2020.1.1
}

A Német Régészeti Intézet (DAI) frankfurti kutatóintézete, a Römisch-Germanische Kommission (RGK) közel százhúsz éves fennállása alatt több alkalommal volt új kutatási módszerek kezdeményezője. A 2010ben megalakult „Technikai részleg” elöször föként az akkor már gyakorlatnak számító nagy felületü archeofizikai vizsgálatokkal, a talaj eltérö mágnesességének mérésén alapuló geomágneses prospekcióval foglalkozott. Ám azóta a tevékenységi köre számos roncsolásmentes vagy minimális roncsolással járó, valamint újabb és újabb leletvizsgálati módszer bevezetésével bövült. Az évek során egyre több vizsgálati módszert kipróbáló csapatunk igazi kompetenciaközponttá fejlödött, amit a 2019-ben kapott elismerés, az új név is tükröz: Referat für Prospektions- und Grabungsmethodik. A Német Régészeti Intézeten belül csak néhány „Referat” (osztály, részleg) müködik, ilyen pl. a teljes müemléki épitészetet és az örökségvédelmi kérdéseket felölelö berlini Architekturreferat. Központunk a saját ásatásaink, terepi programjaink és természettudományos vizsgálataink mellett a kooperációs partnereink számára is rendelkezésre áll, tágabb értelemben pedig lehetőségeinkhez mérten segitjük külső kollégáink munkáját. Már egy évtizede szorosan együttmüködünk magyarországi kutatócsoportokkal. Az MTA Régészeti Intézetében az Alsónyék-Bátaszék újkökori lelöhely feldolgozására nyert OTKA pályázat keretén belül 2011-ben magnetométeres vizsgálatokat végzett az RGK csapata; az alsónyéki, sárközi roncsolásmentes tájrégészeti felmérések és kiértékelésük a mai napig tart. Az ELTE Régészettudományi Intézetének munkacsoportjával pedig két évvel ezelött kezdtünk intenziven együttmüködni az alföldi késö neolitikum tell-településeinek vizsgálatában. Mivel az RGK - a sokféle új felszerelés, müszer segitségével zajló - kutatási módszereinek áttekintése már nem is olyan egyszerü feladat, itt foglaljuk össze, mit és hogyan kutatunk (1. kép).

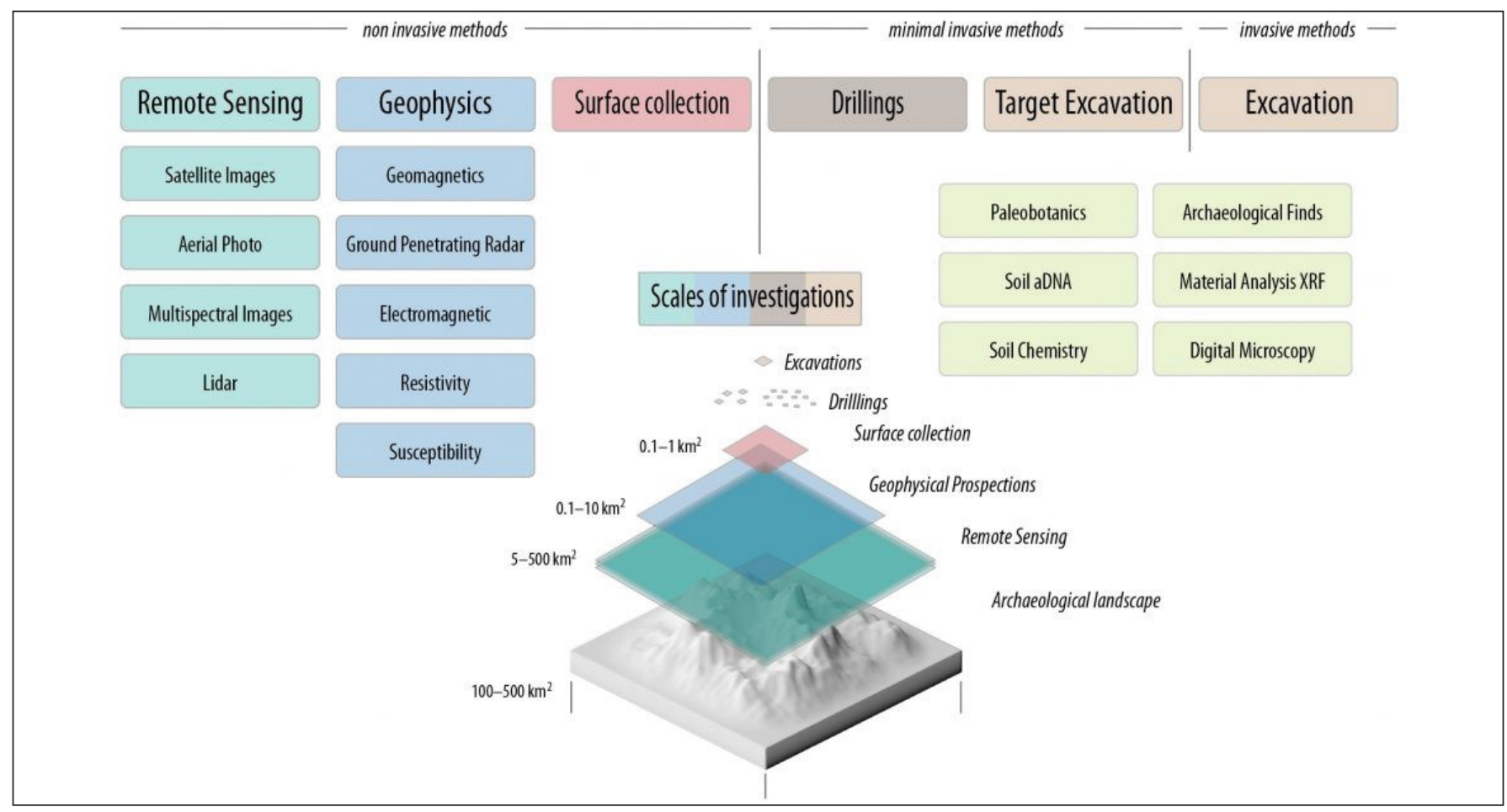

1. kép. Az RGK Prospekciós és Ásatás-módszertani Központja tevékenységének összefoglaló ábrázolása (készitette: K. Rassmann - H. Höhler-Brockmann) 
Knut Rassmann et al. • Bemutatkozik a Német Régészeti Intézet frankfurti prospekciós és ásatás-módszertani központja

\section{A 3D-S MODELLEZÉS ÉS A DRÓNOK BEVETÉSE}

Minden régészeti kutatás - legyen az egy történeti táj, egy lelöhely vagy akár egyetlen lelet vizsgálata a rendelkezésre álló adatok gondos felvételével kezdődik. Egy ideje ezt a 3D-s képalkotás módszerével végezzük (amelyet gyakran SfM-nek - Structure from Motion-nak - nevezünk), hogy minél részletesebb háromdimenziós képet nyerjünk arról a felületröl, amelyet vizsgálni szeretnénk. Egy ilyen modell külö-

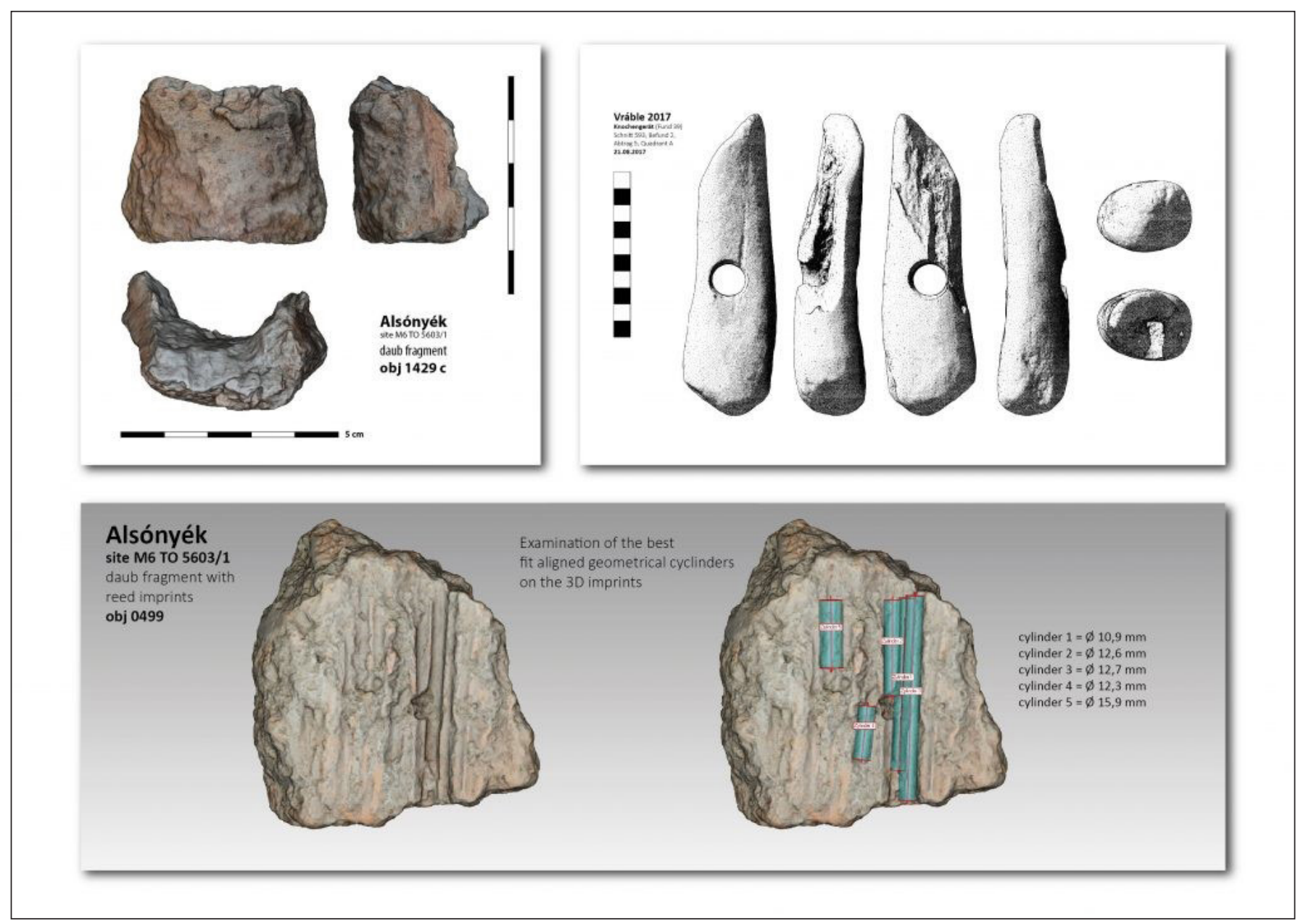

2. kép. Néhány példa különbözö leletek 3D-s digitális dokumentálására (készitette: H. Höhler-Brockmann)

nösen az összetett, többféle információt hordozó helyzetekben segíti a tisztánlátást és az elemzést függetlenül attól, hogy a vizsgálatunk tárgya egy apró paticsrög vagy egy hatalmas rézkori település (2. kép). Csupán a rendelkezésre álló felszerelésünk és a tudományos kérdésfeltevés szab határt és irányt a lehetőségeknek.

A helyszíni vizsgálathoz egy számos elemből álló készlet áll a rendelkezésünkre, amely pl. egy fotózáshoz szükséges mobil állomásernyőből, forgótányérból, a jó megvilágításhoz szükséges lámpatestekből áll - ezek elférnek egy hátizsákban. Ha egy táj felmérése a cél, akkor ún. UAV-rendszert vagy más néven drónokat alkalmazunk (UAV = Unmanned Aerial Vehicle). Ezek azonban sokfélék

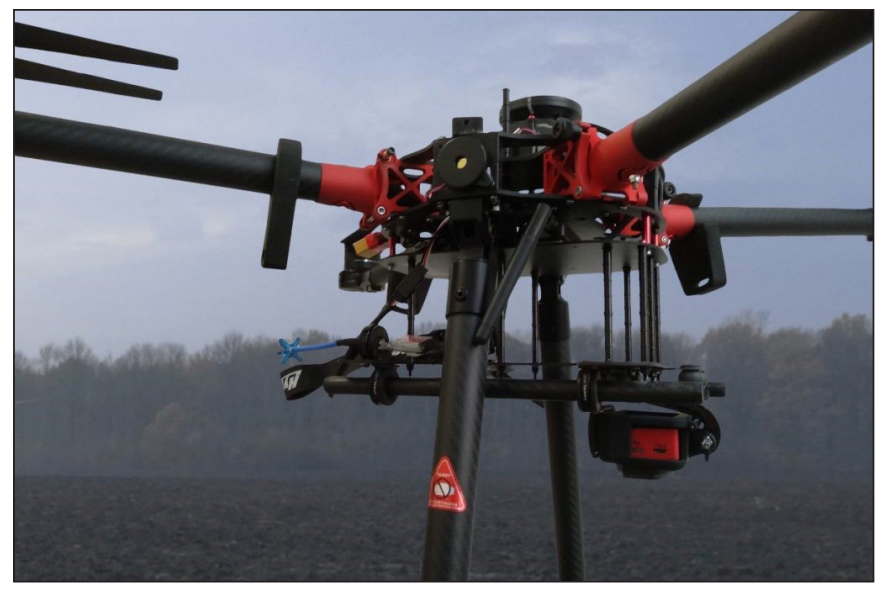

3. kép. Drónbevetés elökészitése a Tisza vidéken, Öcsöd-Kováshalom újkökori lelöhelyen. Itt a teljesen automatizálható drónt multispektrál-szenzorral egészitettük ki (fénykép: H. Höhler-Brockmann) 
Knut Rassmann et al. Bemutatkozik a Német Régészeti Intézet frankfurti prospekciós és ásatás-módszertani központja

lehetnek: a feladatnak megfelelően sokszor egy kis kézitáskában is elférő, gyors felmérésre alkalmas egyszerü fajtát; más esetben akár teljes automatikával, kamerával vagy további mérésre alkalmas müszerekkel (például multispektrál-szenzorral) felszerelt drónt röptetünk (3. kép).

\section{GEOMÁGNESES PROSPEKCIÓ}

Tájrégészeti kutatásainkhoz már 2003 óta használjuk a roncsolásmentes geofizikai vizsgálati módszert. Az évek és a sok bevetés során finomítottuk, tökéletesítettük mind a technikát, mind pedig az ahhoz szükséges tudásunkat. Mára már a terepi kutatásból származó adatainkat többféle program és filter segítségével értelmezzük. Ehhez arra van szükség, hogy az adatok a lehető legjobb minőségben álljanak a rendelkezésünkre többek között azért, hogy a jövőben - valószínüleg a még tökéletesebb módszerekkel végzett kiértékelésük során - új, ma még nem ismert értelmezési lehetőségekre is alkalmasak legyenek. Mindebből az következik, hogy az RGK-ban a folyamatos tanulás, a kísérletezés, a kutatási módszerek különböző fajtáinak összekapcsolása kiemelkedően fontos mind a magunk, mind a széles körü kapcsolatrendszerünk - németországi és más nemzetbeli kollégáink - számára.

Nagy felületek kutatására a 14 szondával rendelkező mérőeszközünket használjuk, amelyet gépi erő mozgat a földeken. A felület hozzáférhetősége és a talaj szerkezete alapján döntjük el, hogy milyen jármühöz csatlakoztatjuk (4. kép). Általában terepjáró vagy a nemrégen vásárolt kvad mellett döntünk. A 14 szondás eszköz előnye abban rejlik, hogy a nem több, mint 3,5 m szélessége miatt utánfutó nélkül is szállítható, mégis alkalmas rövid idő alatt nagy felületek geofizikai átvizsgálására. A kutatott terület nagysága - a földrajzi adottságoktól, a talaj szerkezetétől, állapotától és a szárazabb vagy esős időjárástól függően - naponta a 10-30 hektárt is elérheti.

Az RGK újonnan elnevezett kompetenciaközpontja rendelkezik még egy 5 szondás műszerrel is, amely akár kézi erővel tolható, vagy a kvadhoz csatlakoztatható. Ez a kisebb eszköz nagyszerüen alkalmas kisebb felületek, egy-egy szántóföld szélei vagy nehezen megközelíthető felületek vizsgálatára (5. kép).

Hosszú idő és sok kísérlet során sikerült kialakítanunk ezt a kétféle müszeren alapuló rendszert, amely lehetővé teszi, hogy bonyolult felszínű nagy felületeken számos ,,ablakot” nyithassunk a régészeti szempontból fontos tájban, netán ismert lelöhelyek közvetlen közelében.

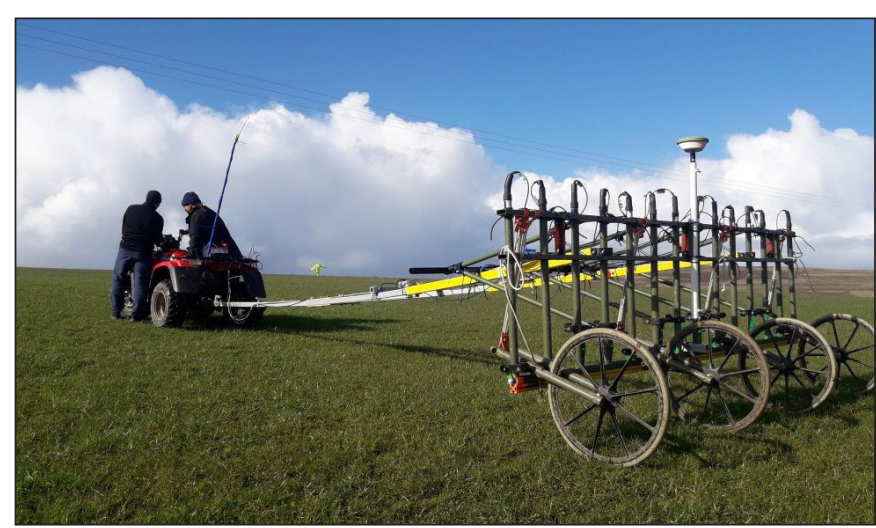

4. kép. A 14 szondás eszköz bevetés közben az írországi Boyne folyó völgyében (fénykép: J. Kalmbach)

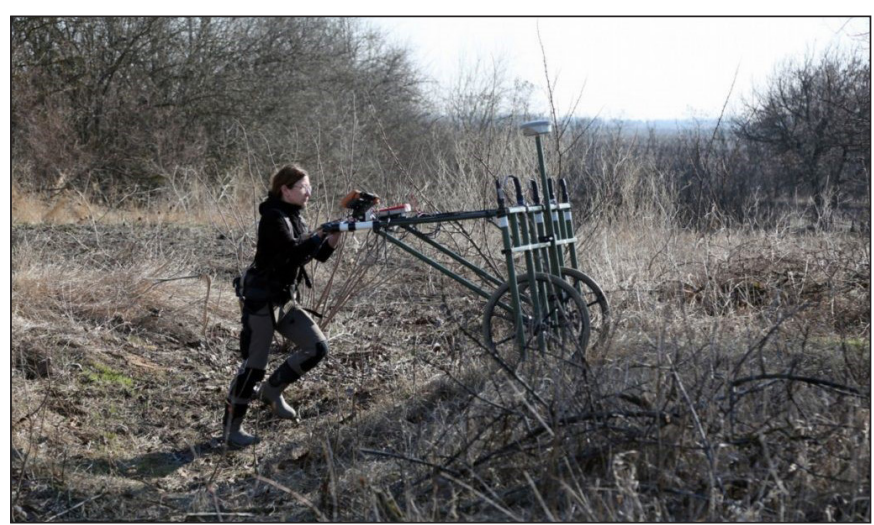

5. kép. Munkában az 5 szondás eszköz a Hódmezővásárhelygorzsai tell-település közelében (fénykép: R. Scholz)

\section{AZ RGK LABORATÓRIUMA}

Vizsgálatunk tárgya a lelet maga és a talajból vett mintaanyag, amely egyre fontosabb régészeti forrás. Roncsolásmentes vizsgálati módszereinket csekély roncsolással járó, ún. minimál-invazív vizsgálatokkal is kiegészítjük. Ide tartoznak a talajfúrásból szerzett földminták. A célzott fúrások helyét az előzetes geomágneses prospekció eredményei alapján tervezzük meg. Ilyen jelentős talajmintát igénylő hely leggyakrabban egy-egy fontos régészeti struktúrán belül fordulhat elő. Leginkább egy településen, egy lakóházon vagy egy temetkezésen belül érdekesek a részletek: milyen az egyes rétegek szerkezete, vastagsága, ezek 
Knut Rassmann et al. • Bemutatkozik a Német Régészeti Intézet frankfurti prospekciós és ásatás-módszertani központja

hogyan változnak a lelőhely egyes részein belül. A földminták rétegeit radiokarbon-kormeghatározással keltezzük, így a régészeti jelenségek kezdetének és végének időpontján kívül a „,belső” kronológiáról is fontos információt kapunk a fúrásmintákból (6. kép). A talajmintákban talált mikroszkopikus maradványok - mint pl. a pollenszemek vagy a szervetlen növényi fitolitok - az egykori növényvilág tanúi. Ám szerencsés esetben makrobotanikai maradványok is vizsgálhatók: a gabonaszemek szenült töredékei vagy a gyümölcsök csonthéj-maradványai az elmúlt korszakok növénytermesztési és táplálkozási szokásairól vallanak.

Egy speciális eszköz, az ún. szukcesszivitásmérő segítségével a talajfuratok mágnesességének változásai is mérhetők, így a függőleges rétegek „története” rekonstruálható. Az üledékmintákban mért foszfátértékek segítenek az egyes időszakokban fénykorukat élő települések intenzitásának, az emberi hatás jelentőségének megismerésében: a tartós, sok emberi és állati bomlásterméket felhalmozó településeken magas foszfátértékeket kapunk. Ha ásatás közben a feltárt felület bizonyos részeiből veszünk talajmintát, akkor a hordozható röntgenfluoreszcens spektroszkóp segítségével végezhetünk talajkémiai méréseket. Az utóbbi években több, mint 5 ezer - részben ásatáson belül, részben lelőhelyen kívül - régészeti szempontból fontos tájszakaszon vett talajmintát vizsgáltunk. Mind gyakorlati, mind pedig etikai megfontolásból (tehát a régészeti örökség védelme szempontjából) lényeges, hogy minden furat felét archiváljuk, ezáltal megőrizzük a jövő számára, hogy az egyre tökéletesebb későbbi módszerekkel is összehasonlítóvá, mérhetővé tegyük a földmintáinkat. Eközben mi magunk is újabb és újabb izgalmas és ígéretes területek felfedezésével kísérletezünk. Legutóbb a lipcsei Max Planck Intézettel együttmüködve talajbaktériumok genetikai vizsgálatába kezdtünk - ez azonban még igazi kísérleti projekt!

A fúrásokból nyert talajminták elemzése és dokumentációja mellett található még egy terület, amelyre az RGK kompetenciaközpontja a laboratóriumi munkák között külön hangsúlyt helyez. Ez nem más, mint a leletek, a tárgyak elemzése a Keyence digitális mikroszkópunk segítségével. Ezzel az eszközzel 2000-szeres nagyításban figyelhetünk meg olyan részleteket, mint pl. az agyagedények készítésének technikai részletei, a nyersanyag

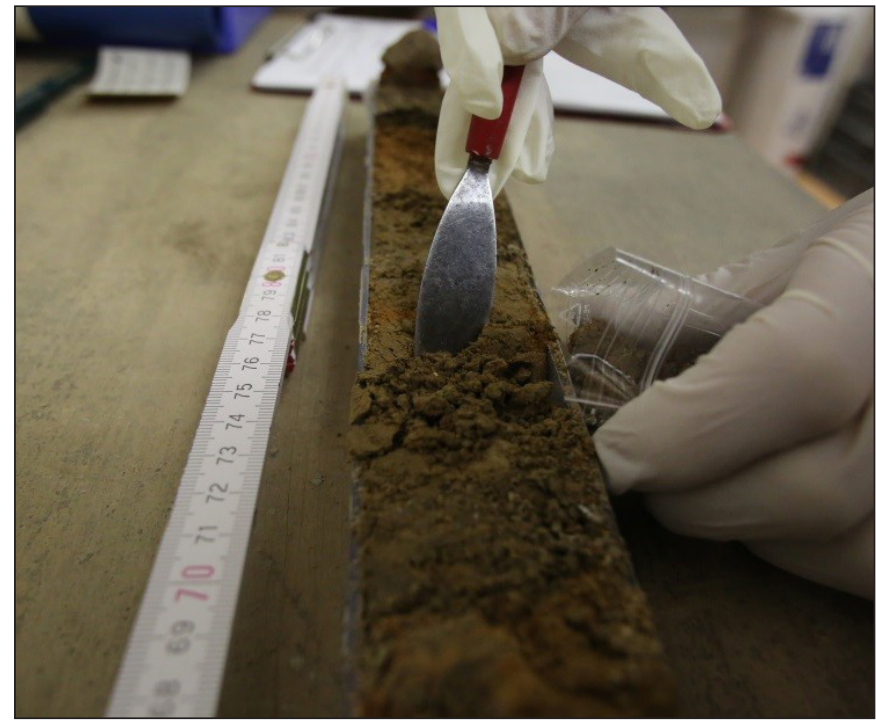

6. kép. Egy földminta belső rétegsora. A félbevágott furat készen áll a dokumentációra és az egyes rétegekböl való mintavételre (fénykép: J. Kalmbach)

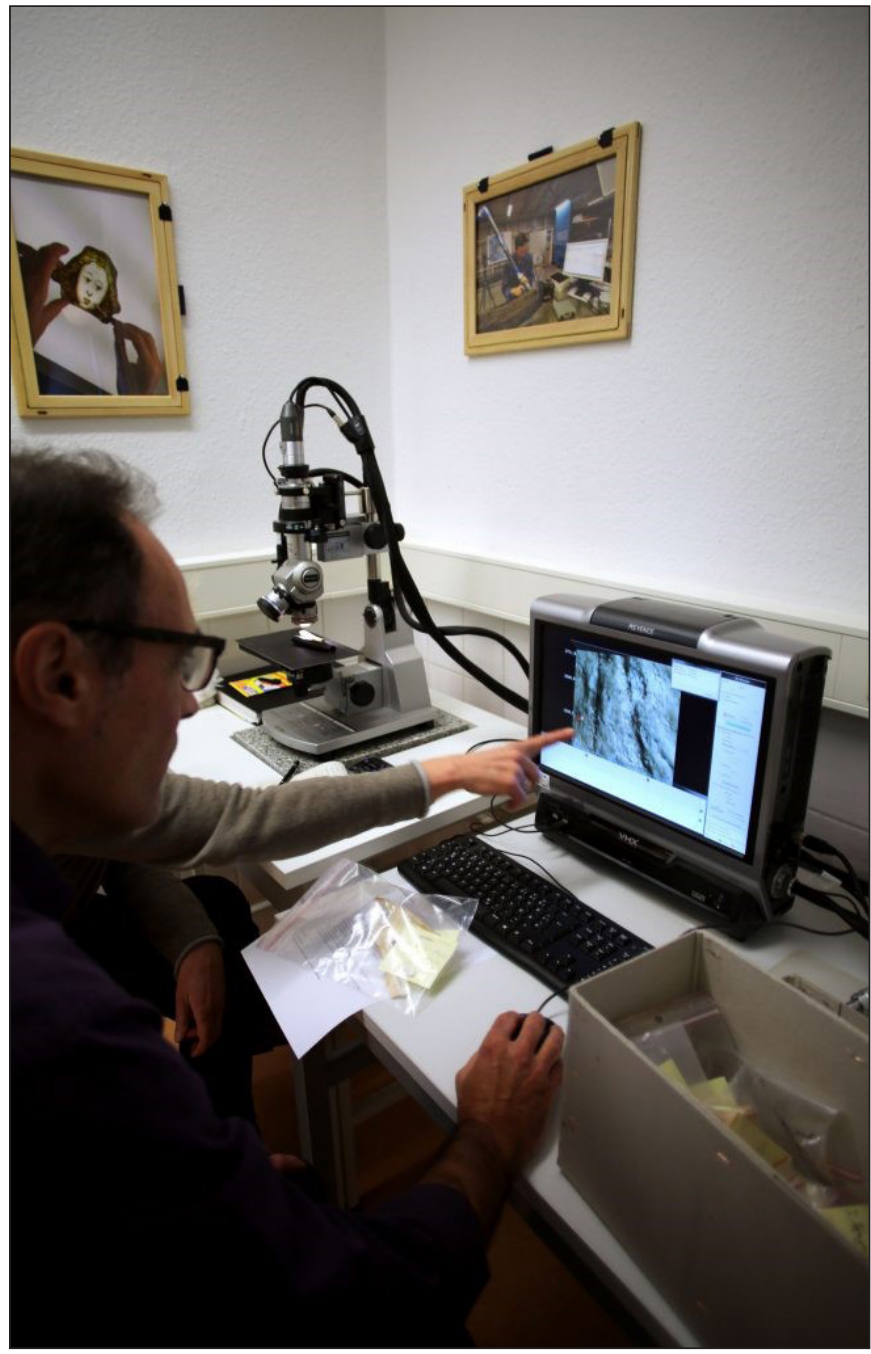

7. kép. Használat közben a digitális mikroszkóp: emberi kéz okozta vágásnyomok szerkezetének vizsgálata a délnyugatnémetországi herxheimi újkökori emberi koponyákon és hosszúcsontokon (fénykép: J. Kalmbach) 
Knut Rassmann et al. Bemutatkozik a Német Régészeti Intézet frankfurti prospekciós és ásatás-módszertani központja

jellemző elemei, valamint a soványítás anyaga. Látványos eredményeket értünk el az egyes eszközök használati nyomainak megfigyelésében, s ezen részletekről pontos, kinagyított felvételeket készítünk. A 3D-s rekonstrukció segítségével a tárgyak felszínének legapróbb részleteit is rögzíthetjük. Az egyik érdekes projektünk jelenleg éppen azt vizsgálja, hogy milyen behatás nyomai láthatók az egyén halálát követően az emberi csontmaradványokon (7. kép). A régészeti leleteken végzett archeometriai és tafonómiai vizsgálatok (amelyek arra irányulnak, mi történt a tárgyakkal, miután a készítőik használták) számos fontos kérdés megválaszolásában segítenek. Megfejthetjük például, hogy miként készültek, hogyan, mire használták, javították-e, újrahasznosították-e, eldobták, netán szándékosan deponálták-e ezeket a tárgyakat. A digitális mikroszkóp végső soron a múltbéli társadalmak működésének megértéséhez járul hozzá.

\section{VÍZ ALATTI RÉGÉSZETI KUTATÁSOK}

A fent ismertetett módszerek mellett a frankfurti RGK érintőlegesen, a módszertani kísérletei kapcsán szerepet vállal a víz alatti régészet néhány szegmensében is. A horvátországi Zadarban müködik az UNESCO víz alatti régészeti kutatóközpontja (https://icua.hr/en), amellyel együttmüködve az RGK munkatársai új, kifejezetten víz alatti viszonyokra alkalmazható dokumentációs módszert fejlesztettek ki, illetve tökéletesítettek. Ez a módszer tette lehetővé egy, az Adriai-tengerben a 16. században elsüllyedt hajóroncs teljes feltárását: a már fent röviden ismertetett SfM-módszert alkalmazva 3D-s fényképek ezrei alapján sikerült a teljes hajó háromdimenziós virtuális modelljét megalkotni. Talán ennél is fontosabb, hogy az ehhez hasonló hajóroncsok állagmegóvása és -megőrzése elérésé-

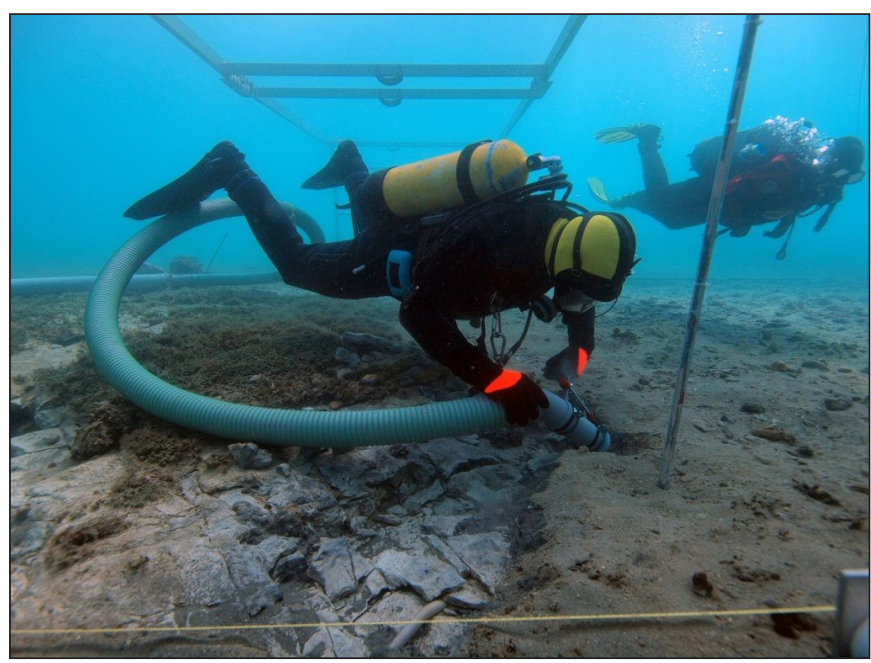

8. kép. A pulai hajóroncs leletegyütteseinek feltárása 2016ban (fénykép: M. Pešić, ICUA Zadar) hez sikerült hatékony módszereket kipróbálnunk a gyakorlatban. Jelenleg a horvát Pula városa előtt elsüllyedt hajóroncs állagmegóvási munkálataiban játszik szerepet az itt kifejlesztett módszer (8-9. kép); de az új, horvát-német projektünk keretében elkezdödött egy közeli késő antik villa és a hozzá tartozó (mára víz alá került) kikötő vizsgálata is.

A Német Régészeti Intézet (DAI) frankfurti székhelyü Römisch-Germanische Kommission (RGK) kutatóintézetének új kutatásairól, projektjeiről, publikációiról és egyéb tudományos híreiről a gyakran frissülő blogbejegyzéseinkből is tájékozódhatnak az érdeklödő olvasók; továbbá saját facebook-oldalunkon is rendszeresen beszámolunk a tudományos és ismeretterjesztő munkánkról.

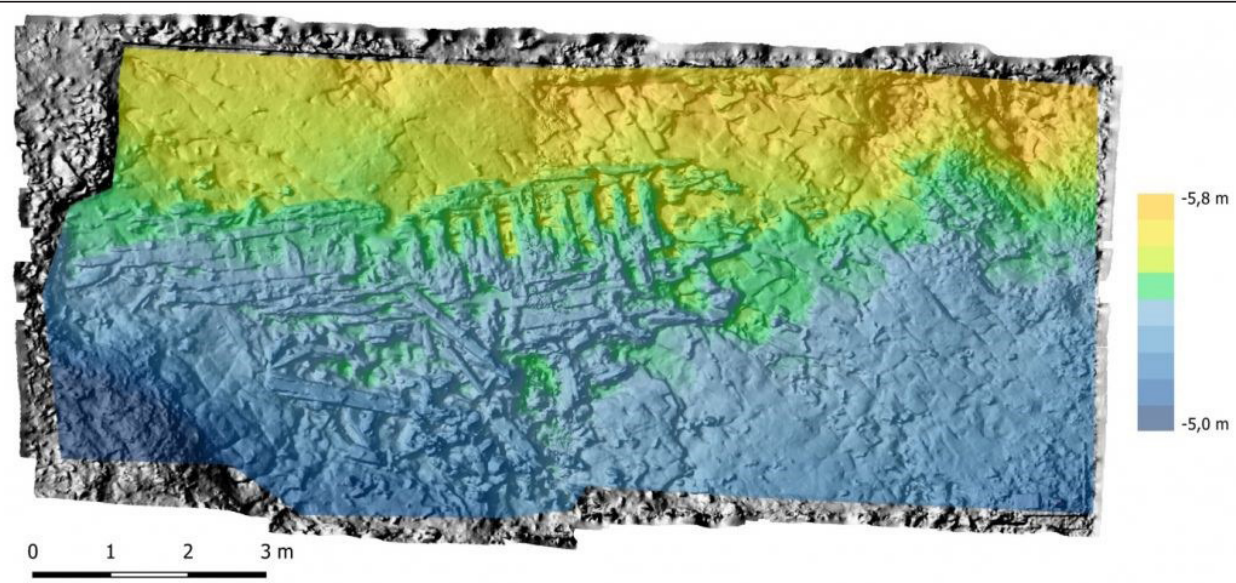

9. kép. A hajóroncs szerkezetének 3D-s modellje (készitette: R. Scholz) 